\title{
Nitrogenous nutrient transfers in oyster ponds: role of sediment in deferred primary production
}

\author{
J. M. Sornin ${ }^{1, *}$, Y. Collos ${ }^{1}$, D. Delmas ${ }^{1, * *}$, M. Feuillet-Girard ${ }^{1}$, D. Gouleau ${ }^{2}$ \\ ${ }^{1}$ Centre de Recherche en Ecologie Marine et Aquaculture de L'Houmeau (CNRS-IFREMER), Case 5, F-17137 L'Houmeau, \\ France \\ ${ }^{2}$ Laboratoire de Géologie Marine de Nantes, Université de Nantes, 2 rue de la Houssinière, F- 44072 Nantes, France
}

\begin{abstract}
The oyster pond under study has a natural sediment bottom and water is changed only once or twice every month depending on tidal height. Between successive water renewals, the pond is a closed system, equivalent to a batch culture in which sinking and biodeposition of particulate matter are the only sources of organic matter to the bottom. Particulate organic matter enrichment of the sediment in winter is followed by intensive ammonification in summer with very limited nitrification. Seasonal nitrogen budgets involving particulate and dissolved phases show that in summer during batch mode periods, ammonium enrichment from the sediment to the overlying water is an order of magnitude higher than the initial nutrient supply in the feed water. This allows a large increase of the phytoplankton biomass. We introduce the term 'deferred' primary production for this phenomenon because of the seasonal lag between particulate nitrogen deposition and dissolved nitrogen fluxes from the sediment.
\end{abstract}

\section{INTRODUCTION}

In coastal and estuarine areas, benthic organic matter mineralization and exchanges at the water/sediment interface are important processes in nutrient cycling (Nixon 1981, Balzer 1984, Hopkinson 1987). Moreover, there is now evidence that benthic nutrient flux contributes significantly to the requirements of pelagic primary producers (Boynton \& Kemp 1985, Hargrave \& Phillips 1986).

Along the French Atlantic coast, shallow oyster ponds (less than $1 \mathrm{~m}$ deep) cover several thousand hectares in marsh areas. These ponds are subjected to high nutrient pulses from feed water at spring tides. As a result of their physical characteristics (small volume, well-defined water exchanges between pond and sea), their large planktonic blooms and easy access, these ponds can be used as models to study biological rate processes.

Early studies of seasonal variations in phytoplankton abundance in such environments (Zanette 1980) showed maximal biomass during summer, when the nutrient supply by feed water was lowest. Similar

\footnotetext{
- Present address: ECOCEAN, avenue Marillac, F-17000 La Rochelle, France

- Addressee for reprints and correspondence
}

observations were made by Robert (1983) who also reported a decrease in external nutrient supply and an increase in chlorophyll a values during summer.

In the present study, seasonal variations of various elements in suspended matter, as well as exchanges between water and sediment, were followed in an oyster pond in order to determine if nutrient regeneration in sediments during summer allows the development of a phytoplankton biomass which cannot be explained by the initial nutrient supply. Conversely, we also determined if, during winter, the supply of organic matter to the sediment would allow sufficient accumulation of nitrogen reserves.

Since shellfish cultures enrich the sediment through biodeposition processes (Kusuki 1981, Sornin et al. 1983) and enhance the recycling of some elements to the overlying water (Kaspar et al. 1985), we made these measurements in an oyster culture sediment area with high sedimentation rate and high organic matter content, and compared these to a control sediment area without oyster farming.

\section{METHODS}

Area description. The oyster pond selected for the present study is a closed earth pond, $50 \mathrm{~cm}$ deep, ca 
$1500 \mathrm{~m}^{2}$ with $5 \mathrm{~m}^{2}$ devoted to above-ground oyster cultures of Crassostrea gigas. This small culture area was chosen to reduce the effect of oysters on phytoplankton consumption in relation to the total quantity available in the pond. The density was 200 oysters $\mathrm{m}^{-2}$, with a mean oyster biomass ranging from $1.7 \mathrm{~g}$ of tissue dry weight at the beginning of farming up to $7.3 \mathrm{~g}, 1 \mathrm{yr}$ later. The pond was submerged during spring tides (tidal constant above 80) which occur every 15 or $30 \mathrm{~d}$. A complete water renewal occurs every month when the pond is emptied at low tide.

Sampling. At the beginning of each batch growth period (between water renewals), pond water was collected daily for $10 \mathrm{~d}$ for analysis of dissolved nutrients.

During batch growth, monitoring of water temperature and sampling of suspended particles were carried out weekly over the year. Particulate matter was collected by filtration through precombusted glass fiber filters (Whatman GF/C) for total and organic seston, particulate nitrogen and chlorophyll a ( $\mathrm{chl}$ a) determination. In this study, only chl a was used to estimate phytoplankton biomass.

Once a month, during water renewal, cores were taken in the culture and in a control area in the same pond. Within $3 \mathrm{~h}$ of collection, each core $(8 \mathrm{~cm}$ diameter, $10 \mathrm{~cm}$ long) was cut into 4 slices: $0-0.5,0.5-1,1-2$ and $2-5 \mathrm{~cm}$. Then, interstitial water was extracted by centrifugation for dissolved nutrient analysis. The sediment was then freeze-dried for total particulate nitrogen and for primary amino nitrogen (PAN, i.e. proteins and amino acids) determinations.

In order to estimate sediment accumulation and resuspension, 2 sediment trap models were used. Briefly, a plastic box, buried at the sediment surface, with a mouth protected by a honeycomb style baffle, trapped all sedimenting material (net sedimentation + local resuspension) with limited under- or overtrapping, as the cells of the baffle have a height/diameter ratio $=3$ (Gardner 1980b). A smooth plastic plate, lying at the sediment surface, provided an estimate of net sedimentation assuming an equilibrium between resuspension output and input as this was the less efficient collector (Gardner 1980a).

These sediment traps were set and retrieved every month in the control area and under oyster cultures. Hence, after ignition of the collected material $(4 \mathrm{~h}$ at $450^{\circ} \mathrm{C}$ ), we could estimate monthly rates of mineral sediment accumulation (raising of the sediment level) and resuspension.

Actual nutrient fluxes (DF) were measured in situ during short-term experiments $(24 \mathrm{~h})$ using dark incubators lying on the sediment. Water samples were taken hourly from the benthic chamber (volume $=31 \mathrm{l}$, area $=0.126 \mathrm{~m}^{2}$ ) for dissolved nutrient analysis (Gouleau et al. 1986).
Analysis. Dissolved nutrients (nitrate, nitrite, ammonium and soluble reactive phosphorus) were measured on a Skalar continuous flow analyzer (Strickland \& Parsons 1968). Dissolved organic nitrogen was not measured. $\mathrm{Chl}$ a was estimated by the fluorometric method of Holm-Hansen et al. (1965). Primary amino nitrogen was measured by fluorescence of orthophtaldialdehyde derivatives of constitutive amino acids (Petty et al. 1982) freed by acid hydrolysis $(5.8 \mathrm{~N} \mathrm{HCl}$ for $20 \mathrm{~h}$ at $105^{\circ} \mathrm{C}$ ). Total particulate nitrogen was determined on an Erba Science Model 1500 nitrogen analyzer with sample processing according to Hedges \& Stern (1984).

Calculation. The accumulated stock (AS) of total particulate nitrogen was estimated from the rate of surface sediment accumulation and its particulate nitrogen content measured in the $0-0.5 \mathrm{~cm}$ slice.

Total particulate nitrogen degradation was estimated for a $2 \mathrm{~cm}$ thickness of sediment by difference between the theoretical stock (TS) of particulate nitrogen (initial + accumulated stock) and the measured stock. We consider that the measured stock $\left(\mathrm{MS}, \mathrm{g} \mathrm{m}^{-2}\right.$ ) is given by the formula:

$$
\mathrm{MS}=\sum \frac{\mathrm{P}_{\mathrm{j}} \times \mathrm{TPN}_{\mathrm{j}} \times \mathrm{T}_{\mathrm{j}} \times 10^{3}}{\mathrm{~W}_{\mathrm{j}}+100}
$$

where $\mathrm{j}=$ sediment level; $\mathrm{T}=$ thickness $(\mathrm{mm})$; $\mathrm{P}=$ wet sediment density $\left(\mathrm{g} \mathrm{cm}^{-3}\right)$; TPN $=$ total particulate nitrogen content ( $\%$ of sediment dry weight); $\mathrm{W}=$ water content ( $\%$ of sediment dry weight).

The theoretical stock is given by

$$
\mathrm{TS}=\mathrm{MS}_{\mathrm{i}}+\mathrm{AS}
$$

where $\mathrm{MS}_{\mathrm{i}}=$ initial measured stock $\left(\mathrm{g} \mathrm{m}^{-2}\right) ; \mathrm{AS}=$ accumulated stock $\left(\mathrm{g} \mathrm{m}^{-2}\right)$.

A similar calculation was carried out to estimate variations of the dissolved inorganic nitrogen stock (nitrate, nitrite and ammonium) in interstitial water. Rates of stock enrichment or depletion (in $\mu \mathrm{mol} \mathrm{m}^{-2} \mathrm{~h}^{-1}$ ) were estimated at monthly intervals during the study period (February 1985 to March 1986).

The theoretical flux (TF) of dissolved inorganic nitrogen was calculated from concentration gradients measured between the 2 levels $0-0.5 \mathrm{~cm}$ and $0.5-1 \mathrm{~cm}$ (Berner 1976):

$$
\mathrm{TF}=\phi_{0} \mathrm{D}_{0} \frac{\mathrm{dC}}{\mathrm{dx}}-\frac{\mathrm{C}_{0} \mathrm{~F}_{\mathrm{s}}}{\mathrm{P}_{\mathrm{s}}} \frac{\phi_{\mathrm{x}}}{1-\phi_{\mathrm{x}}}
$$

where TF $=$ theoretical flux of the dissolved compound between the sediment and water, measured negatively towards the bottom $\left(\mu \mathrm{mol} \mathrm{m}{ }^{-2} \mathrm{~h}^{-1}\right) ; \mathrm{F}_{\mathrm{s}}=$ flux of solid particles towards the sediment due to accumulation $\left(\mathrm{g} \mathrm{m}^{-2} \mathrm{~h}^{-1}\right) ; \mathrm{P}_{\mathrm{s}}=$ mean density of solid particles $(2.65 \mathrm{~g}$ dry weight per $\mathrm{cm}^{3}$ dry sediment); $\mathrm{C}_{0}=$ dissolved 
compound concentration at the sediment surface $(0-0.5 \mathrm{~cm})\left(\mu \mathrm{M}\right.$ or $\left.10^{3} \mu \mathrm{mol} \mathrm{cm}{ }^{-3}\right) ; \mathrm{D}_{0}=$ diffusion coefficient at the water-sediment interface $\left(10^{-4} \mathrm{~cm}^{-2} \mathrm{~s}^{-1}\right.$ in mud; Billen 1982); $\phi_{0}=$ porosity at the water sediment interface; and $\phi_{\mathrm{x}}=$ porosity at a depth $\mathrm{x}$ below which this porosity remains constant.

When ammonium release by fluxes in each batch mode period exceeded the standing stock depletion of $\mathrm{NH}_{4}$ in pore water it was assumed that the difference was due to ammonification. Therefore, the ammonification rate AR $\left(\mu \mathrm{mol} \mathrm{cm} \mathrm{cm}^{-3} \mathrm{~h}^{-1}\right)$ was roughly determined by the formula

$$
\mathrm{AR}=(\mathrm{DF}-\Delta \mathrm{MS}) \times 1 / \mathrm{T} \times 10^{-4}
$$

where DF $=$ measured dark flux of ammonium $(\mu \mathrm{mol}$ $\left.\mathrm{m}^{-2} \mathrm{~h}^{-1}\right) ; \Delta \mathrm{MS}=$ rate of change of the dissolved porewater ammonium stock measured during batch periods $\left(\mu \mathrm{mol} \mathrm{m}^{-2} \mathrm{~h}^{-1}\right)$; and $\mathrm{T}=$ thickness of the sediment slice (cm).
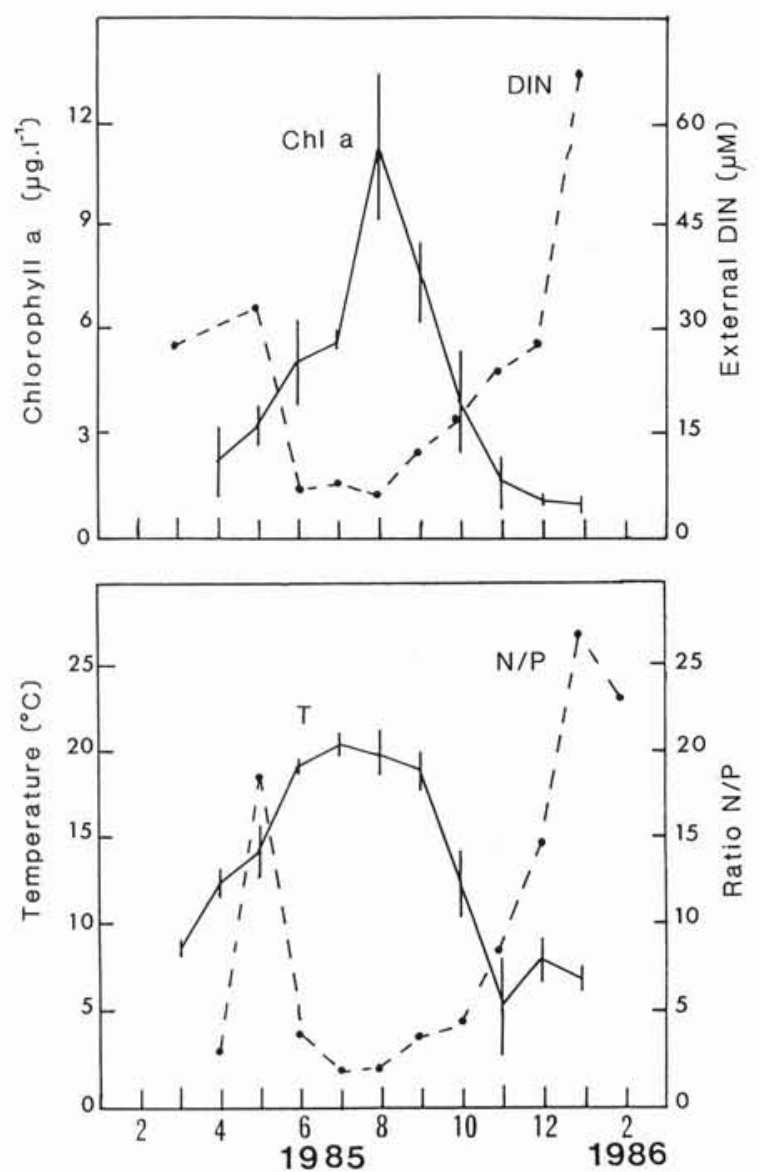

Fig. 1. Seasonal changes in dissolved inorganic nitrogen (DIN) and N/P ratio by atoms in supplies by feed water before each batch mode period; chlorophyll a ( $\mathrm{chl} \mathrm{a}$ ) and temperature (T) in the pond water column during batch mode period

\section{RESULTS}

\section{Algal biomass and nutrients in the water column}

Microalgal biomass estimated from chl a in suspended particulate matter varied over an order of magnitude during the study period, and showed a regular increase from spring to summer with a maximum of $11.3 \mu \mathrm{g} \mathrm{l}^{-1}$ in August. Values then decreased to a minimum of $1.1 \mu \mathrm{g} \mathrm{l}^{-1}$ in December (Fig. 1).

Dissolved inorganic nitrogen (DIN) concentrations in feed water followed a seasonal trend which was opposite to that of chl $a$ in pond water: concentrations were lowest in summer $(6.3 \mu \mathrm{M}$ in August) and highest in winter $(66.7 \mu \mathrm{M})$. In the feed water, the N/P (DIN/ soluble reactive phosphorus) ratio (by atoms) ranged between 1.5 in July and 26.6 in January. The lowest values occurred during summer when the water had a very low DIN content.

The DIN in feed water was used to calculate the potential production of phytoplankton [1 $\mu \mathrm{g} \mathrm{chl} \mathrm{a} \mathrm{pro-}$ duced by $1 \mu \mathrm{mol} \mathrm{N}$ consumed (Maestrini \& Robert 1981)]. The potential chl a production could be compared to values actually measured in the pond. The difference (the equivalent amount of DIN in excess or in deficit; Table 1) showed that negative values occurred in June, July and August, i.e. in these months the observed chl a was greater than the potential chl $a$.

Water temperature increased regularly up to maximal values in August (over $21^{\circ} \mathrm{C}$ ), then decreased to $2{ }^{\circ} \mathrm{C}$ in November. A highly significant positive correlation $(\mathrm{r}=+0.83, \mathrm{n}=36, \mathrm{p}<0.01)$ existed with $\mathrm{chl}$ a but there was a negative correlation $(\mathrm{r}=-0.79, \mathrm{n}=10$, $\mathrm{p}<0.01$ ) between temperature and DIN input by feed water.

Table 1. Dissolved inorganic nitrogen balance (DIN Bal.) estimated as the difference between the amounts of chlorophyll a that could potentially be produced from feed water dissolved inorganic nitrogen (Pot. chl a) and the amounts of observed chlorophyll a (Obs. chl a), assuming that $1 \mu \mathrm{g} \mathrm{chl} a$ is produced by $1 \mu \mathrm{mol} \mathrm{N}$ consumed. Negative values correspond to DIN supplied by a source other than feed water

\begin{tabular}{|lccc|}
\hline Month & $\begin{array}{c}\text { Pot. chl } a \\
\left(\mu \mathrm{g} \mathrm{I}^{-1}\right)\end{array}$ & $\begin{array}{c}\text { Obs. chl } a \\
\left(\mu \mathrm{g} \mathrm{l}^{-1}\right)\end{array}$ & $\begin{array}{c}\text { DIN Bal. } \\
\left(\mu \mathrm{mol}^{-1}\right)\end{array}$ \\
\hline Apr & 6.0 & 3.1 & 2.9 \\
May & 32.5 & 3.5 & 29.0 \\
Jun & 7.2 & 7.3 & -0.1 \\
Jul & 7.7 & 9.3 & -1.6 \\
Aug & 6.2 & 15.5 & -9.3 \\
Sep & 10.8 & 8.5 & 2.3 \\
Oct & 18.1 & 8.5 & 15.3 \\
Nov & 36.3 & 1.2 & 35.1 \\
Dec & 27.6 & 0.9 & 26.7 \\
Jan & 66.7 & 1.1 & 65.6 \\
\hline
\end{tabular}




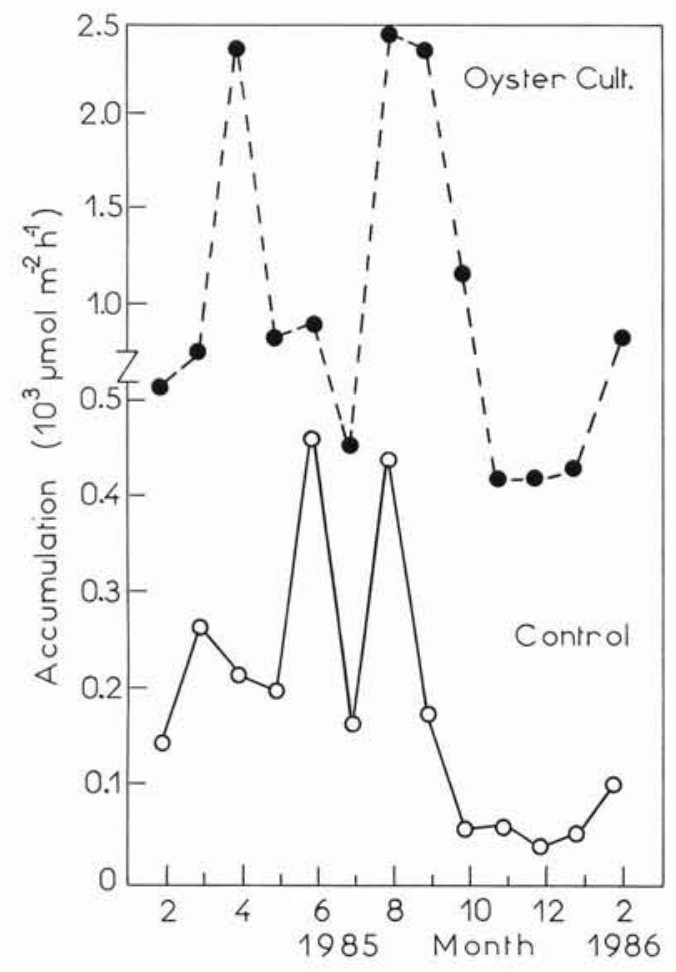

Fig. 2. Accumulation of total particulate nitrogen (TPN) in control and experimental sediments

\section{Sediment particulate nitrogen}

In both the oyster and control zones, the sediment consisted of mud, with $80 \%$ of particles smaller than $10 \mu \mathrm{m}$. Accumulation rates estimated from sediment traps showed identical seasonal trends in the control and oyster culture areas: high values of total particulate nitrogen in spring and summer, and low values in fall (Fig. 2). However, in spring the accumulation under the oysters was an order of magnitude higher than in the control area.

Generally, TPN levels decreased with sediment depth in the first $5 \mathrm{~cm}$. In the control sediment, maxima were observed in winter with nitrogen comprising $0.39 \%$ of sediment dry weight in February. A notable depletion in May and June led to a decrease of TPN values $(0.2 \%$ at $1 \mathrm{~cm}$ depth). Under the oysters, sediments were clearly enriched in TPN; at the surface, values were up to $0.46 \%$ in February and remained high until the beginning of summer, then decreased and exhibited rapid variations which destabilized the depth distribution of TPN. From September to January, successive enrichment and depletion periods could be observed over several centimeters. A stable depth profile reappeared only in February.

\section{Sediment primary amino nitrogen}

PAN accumulation represented between 10 and $20 \%$ of TPN input at the sediment surface and showed the same trend as TPN.

However, in contrast to TPN, the depth distribution of PAN was maintained throughout the year in the control sediment (Fig. 3A) and in the oyster zone (Fig. 3B); values ranged between 246 and $551 \mu \mathrm{g} \mathrm{N}$ $\mathrm{g}^{-1}$ in control sediments and reached $689 \mu \mathrm{g} \mathrm{N} \mathrm{g}^{-1}$ in the oyster zone. Moreover, the PAN standing stock showed a clear decrease during summer, followed by a progressive increase over the whole sediment thickness.

\section{(A) CONTROL}

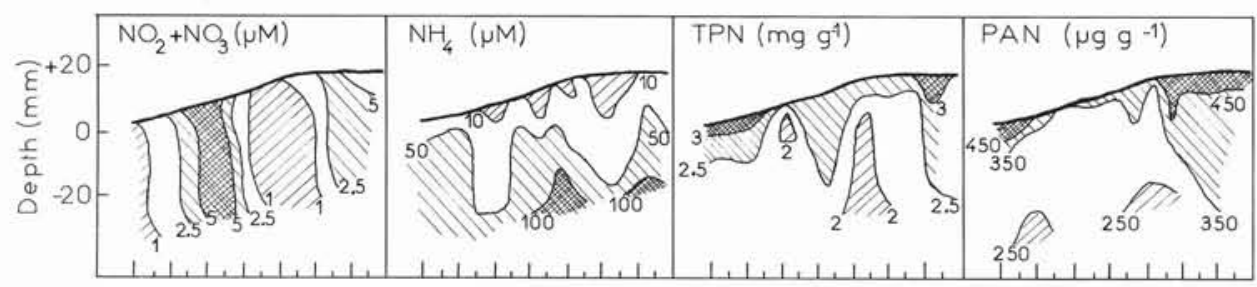

(B) OYSTER CULTURE

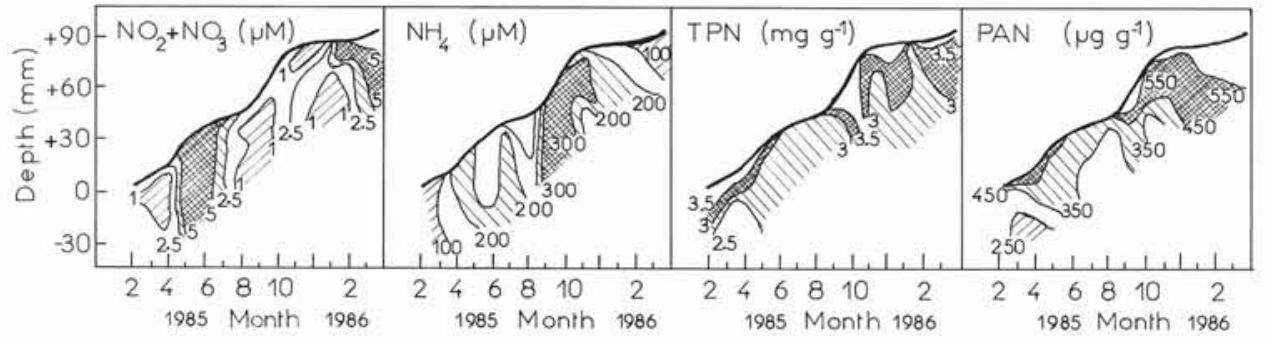

Fig. 3. Changes in nitrogenous compounds of surface sediments and interstitial water in (A) control and (B) experimental area. Positive values show the raising of the sediment interface level induced by 


\section{Ammonium in interstitial water}

In control sediments, ammonium distribution exhibited a depth profile which was the reverse of that observed for previous compounds: concentrations were low at the surface and increased with depth (Fig. 3A), varying between 3.3 and $120.2 \mu \mathrm{M}$. The lowest values were observed at the end of summer, rapidly followed by high values which remained so during fall. Under the oyster culture, the concentrations in the sediment were much higher (Fig. 3B) and reached $554 \mu \mathrm{M}$ in September at $1 \mathrm{~cm}$ depth.

Theoretical fluxes (TF) varied drastically in the control sediment (Fig. 4) without any clear seasonal trend. They ranged from -120 (flux towards the sediment) to +200 $\mu \mathrm{mol} \mathrm{m}{ }^{-2} \mathrm{~h}^{-1}$ (upward flux). In the oyster zone sediment, the range of variations was much higher (Fig. 4): -20 to $+1100 \mu \mathrm{mol} \mathrm{m}^{-2} \mathrm{~h}^{-1}$. A clear increase in upward flux was noted during summer and early fall.

Control sediment fluxes measured in situ in dark incubators (DF) showed little seasonal variation (Fig. 4), with values ranging from 12 (April) to 46 $\mu \mathrm{mol} \mathrm{m} \mathrm{m}^{-2} \mathrm{~h}^{-1}$ (September). Within the oyster zone, amplitudes were much more marked with fluxes of 953 and $77 \mu \mathrm{mol} \mathrm{m} \mathrm{m}^{-2} \mathrm{~h}^{-1}$ in July and March, respectively. Generally, we found good agreement between theoretical flux estimations and in situ measurements.

\section{Nitrate and nitrite in interstitial water}

Nitrate and nitrite gradients could not be detected over the 5 first cm at any time of year in control sediments (Fig. $3 \mathrm{~A})$. Concentrations increased from winter to July in the entire sediment thickness to a maximum of $6.8 \mu \mathrm{M}$ and then decreased gradually from the end of summer to December. A new enrichment was seen only in January.

Similarly, sediment concentration below the oysters increased gradually up to $7 \mu \mathrm{M}$ in July (Fig. 3B). However, in the fall the decrease was shorter in duration, and the sediment became enriched again in November. A gradient occurred in winter with concentrations slightly higher at the surface.

These low levels, in control as well as in oyster zones, led to weak theoretical fluxes (TF) which were near zero with 2 exceptions: -115 and $+65 \mu \mathrm{mol} \mathrm{m}^{-2} \mathrm{~h}^{-1}$ in February and November respectively. Actual fluxes measured in situ (DF) were not detectable. In these sediments, nitrate and nitrite standing stocks as well as their fluxes were of little importance compared to ammonium.

\section{Nitrogen budget}

Calculations described above made it possible to establish budgets for the different nitrogenous forms

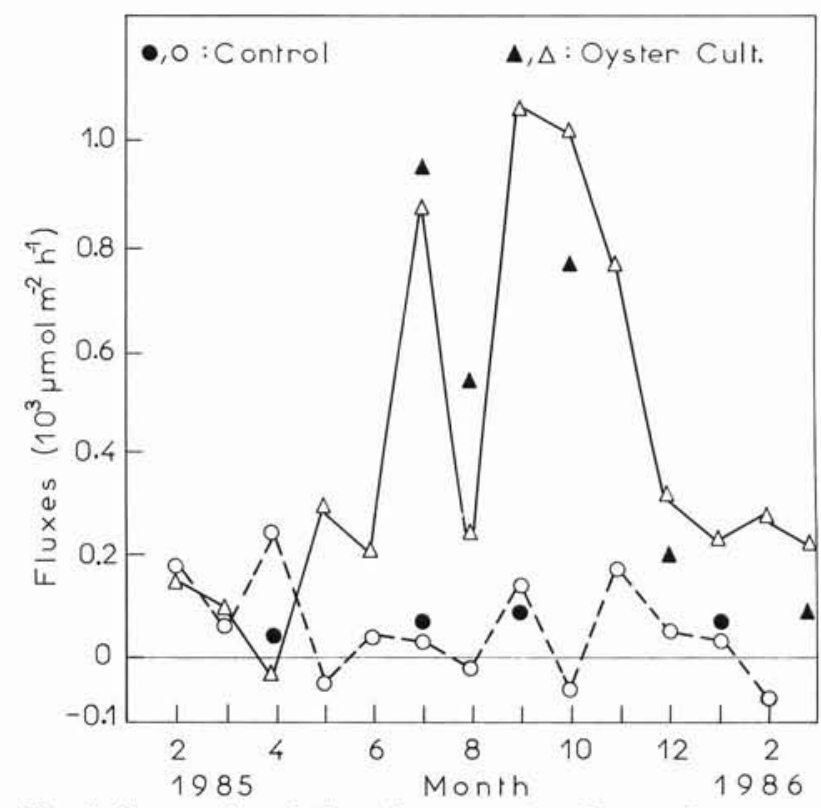

Fig. 4. Seasonal variations in ammonium fluxes. Open symbols: fluxes calculated from concentration gradients between $0-0.5 \mathrm{~cm}$ and $0.5-1 \mathrm{~cm}$; closed symbols: fluxes measured in dark bell jars in situ. Positive values represent upward fluxes

for each season as well as the enrichment or depletion rates of standing stocks (Fig. 5). As dissolved organic nitrogen (DON) was not measured, complete mass balance calculations were not possible. Few studies have considered DON flux across the sediment-water interface. DON flux has been reported to be either relatively unimportant (Nixon 1981, Hopkinson 1987) or to approximate $\mathrm{NH}_{4}$ flux following a similar seasonal time course (Boucher \& Boucher-Rodoni 1988). Thus, we can expect that the general trends were not significantly affected.

Seasonal variations of particulate supply and dissolved inorganic nitrogen release indicated an enrichment in winter with a mean of $+140 \mu \mathrm{mol} \mathrm{m}^{-2} \mathrm{~h}^{-1}$ in the control area and about 4 times higher under oysters $\left(+587 \mu \mathrm{mol} \mathrm{m}^{-2} \mathrm{~h}^{-1}\right)$. Conversely, depletion of particulate nitrogen standing stock took place from spring to fall in control sediments $\left(-174\right.$ and $-79 \mu \mathrm{mol} \mathrm{m}^{-2} \mathrm{~h}^{-1}$ respectively), and only in the fall in the oyster zone $\left(-148 \mu \mathrm{mol} \mathrm{m}^{-2} \mathrm{~h}^{-1}\right)$.

In interstitial water, seasonal enrichment or depletion rates of DIN stocks were relatively small: about $+1 \mu \mathrm{mol} \mathrm{m}{ }^{-2} \mathrm{~h}^{-1}$ in control sediments and $+11 \mu \mathrm{mol}$ $\mathrm{m}^{-2} \mathrm{~h}^{-1}$ in summer under oysters. These were essentially due to ammonium since variations in nitrate stocks were very limited.

Approximate total ammonification rates in the $0-0.5$ $\mathrm{cm}$ slice ranged between $0.5 \times 10^{-3}$ and $40.3 \times 10^{-3}$ $\mu \mathrm{mol} \mathrm{cm}{ }^{-3} \mathrm{~h}^{-1}$ in the control zone and $18.0 \times 10^{-3}$ to $220.0 \times 10^{-3} \mu \mathrm{mol} \mathrm{cm}{ }^{-3} \mathrm{~h}^{-1}$ in the oyster zone. 
CONTROL
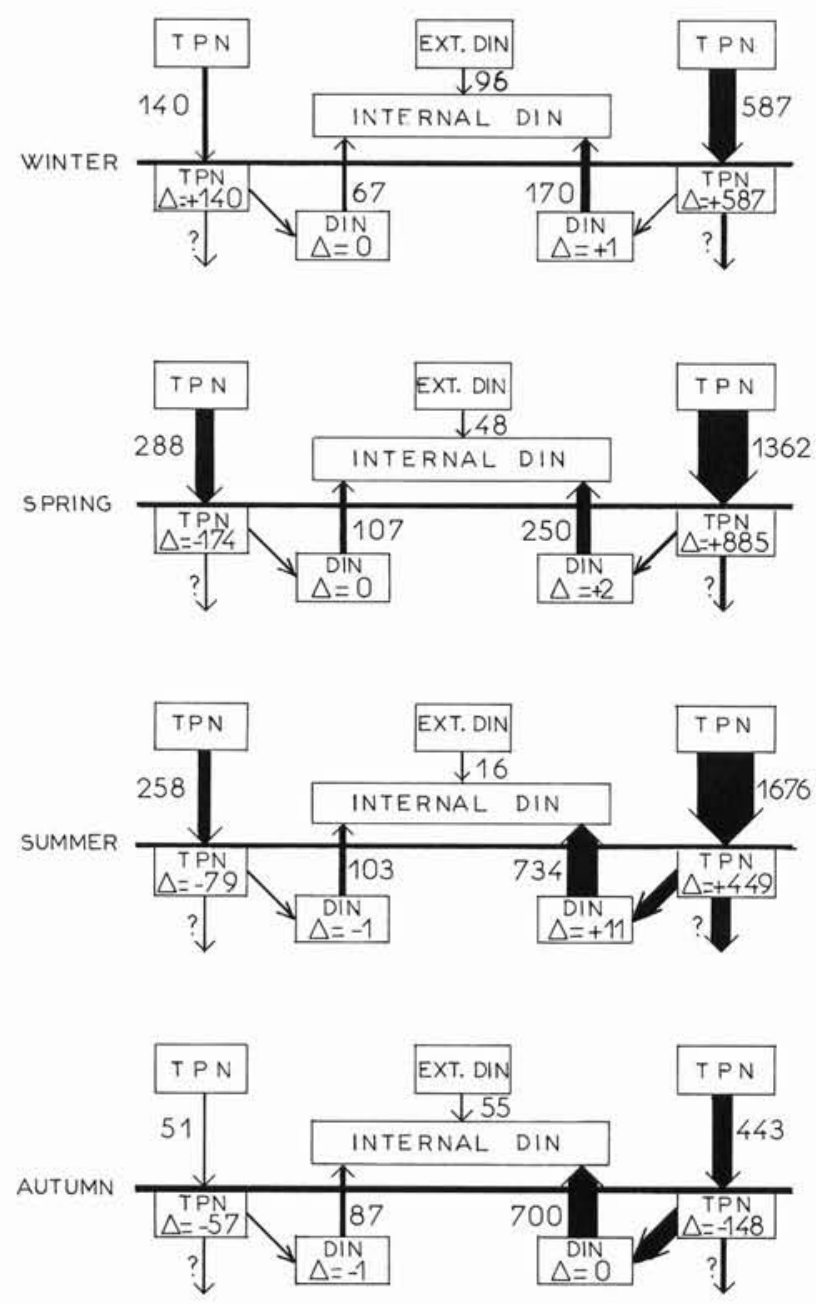

Fig. 5. Mean rates of seasonal exchanges inside (boxes) and between (arrows) the different nitrogen stocks actually measured in the oyster pond $\left(\mu \mathrm{mol} \mathrm{m} \mathrm{m}^{-2} \mathrm{~h}^{-1}\right)$. Seasonal values are averages of 3 monthly measurements between February 1985 and March 1986. TPN: total particulate nitrogen; DIN: dissolved inorganic nitrogen; EXT. DIN: external feed water dissolved inorganic nitrogen

\section{DISCUSSION}

In an oyster pond, phytoplankton standing stocks are related to the carrying capacity of the environment and grazing by oysters. In summer, grazing accounts for only $2 \%$ of the phytoplankton standing stock (Sornin et al. 1987). Obviously, nutrients are the main controlling factor. Variations in phytoplankton biomass in the pond are inversely related to the amount of nutrients supplied by feed water (Fig. 1). In winter, coastal waters are strongly enriched by drainage from agricultural areas. On the other hand, in summer, rainfall is reduced and drainage does not affect nutrient levels in coastal waters. Moreover, phytoplankton blooms in coastal areas lead to nutrient depletion in feed water. Therefore, between June and September, the difference between maximal chl a observed and the potential level of chl a estimated from DIN levels (Table 1) gives a nitrogen deficit. This is accompanied by a feed water N/P ratio below 5 (Fig. 1) which should lead to nitrogen $(\mathrm{N})$ limitation of primary production if we assume an N/P uptake ratio of 16 by phytoplankton (Redfield et al. 1963, Robert et al. 1982). The discrepancy between these trends illustrates the need for an alternate $\mathrm{N}$ source besides that in external feed water brought in during a tide.

As the oyster pond under study is a closed system between water renewals, the only 2 major sources of nutrients are sediment and oysters. Concerning the latter, we have assumed a steady state between growth of phytoplankton and grazing by oysters and other organisms. This assumption is based on the observation (Fig. 6) that, in bottles containing water from the pond (thereby removing the phytoplankton from grazing pressure) and incubated in situ, chl a increased rapidly, while at the level of the whole pond, there is no change in phytoplankton standing stock in the water on short time scales (order of a day). Moreover, oysters are not net producers of DIN as their uptake of particulate nitrogen exceeds their release in dissolved form.

On a seasonal time scale, the observed increase in phytoplankton biomass must, therefore, be attributed to the nutrient supply from the sediment. This probably originates from organic matter degradation and mineralization taking place in summer (Billen 1977 , Jørgensen \& Sørensen 1985). This phenomenon leads to a decrease in sediment $\mathrm{N}$ compounds, which is particularly notable for the PAN. These amino compounds are more easily degraded than other common

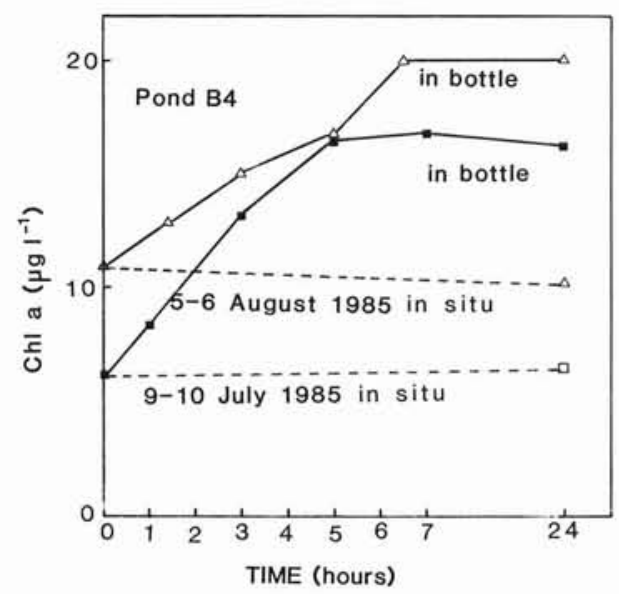

Fig. 6. Short-term changes in chlorophyll $a$ in suspended matter. (---) in situ: whole water sample; $(-)$ in bottle: 1.51 sample incubated in a 21 polycarbonate bottle floating at the pond's surface 
$\mathrm{N}$-containing macromolecules (Christensen et al. 1983).

Conversely, in winter, organic matter degradation is low while TPN supply is high, leading to sediment enrichment in particulate organic matter. The level of organic matter (nitrogen, PAN) is clearly higher in sediments below oysters (Kusuki 1981, Sornin et al. 1983, Feuillet-Girard et al. 1988). In the pond studied here, the sediment richness under oysters was due to particulate organic supplies by sedimentation plus supplies by biodeposition which can increase the deposited quantities by a factor of 20 (Sornin et al. 1987).

Mineralization periods, mainly leading to seasonal release of ammonium, were particularly marked in sediments enriched by the large organic supplies of biodeposits in spring and summer (above $1000 \mu \mathrm{mol} \mathrm{N}$ $\mathrm{m}^{-2} \mathrm{~h}^{-1}$ ). These led to a lowering of the redox potential which became less than $+50 \mathrm{mV}$ at the $0-0.5 \mathrm{~cm}$ sediment depth, and negative below that (results not shown). These oxidoreduction conditions do not allow nitrification to proceed when the $\mathrm{pH}$ is near 7 (Billen 1977), and explain the low levels of nitrate in interstitial waters. Maximal rates of ammonification correspond to periods of high bacterial activity: during spring in control sediment, and late summer and fall in sediments under oysters. These rates are of the same order of magnitude as those found by Billen (1977): between 0.7 and $10.8 \times 10^{-3} \mu \mathrm{mol} \mathrm{cm}{ }^{-3} \mathrm{~h}^{-1}$, by Blackburn (1980): $11.9 \times 10^{-3} \mu \mathrm{mol} \mathrm{cm}{ }^{-3} \mathrm{~h}^{-1}$ and by Henricksen et al. (1984): $46.8 \times 10^{-3} \mu \mathrm{mol} \mathrm{cm} \mathrm{cm}^{-3} \mathrm{~h}^{-1}$.

The time lag observed in the different stocks indicates that sediments are a nutrient reservoir. Thus, the TPN stock is enriched in winter and supplies $\mathrm{N}$ which is mineralized and liberated in summer in the water column. Such seasonal lags have been described for oxygen uptake (Hargrave 1978) and for organic carbon and nitrogen mineralization (Kemp \& Boynton 1984, Rudnick \& Oviatt 1986). This phenomenon allows a 'deferred' primary production in summer. The seasonal trends depicted above are related to the increase in surface irradiance and subsequent temperature changes in spring and summer which has 2 effects: an increase in biological activity such as DIN consumption by phytoplankton (Collos et al. 1988), ammonification by bacteria, bioirrigation by meio- and macro-fauna, and a greater diffusion rate for dissolved compounds in interstitial waters (Krom \& Berner 1980).

In summer, when the nutrient deficit is most noticeable, the control sediment can provide (TF) up to $100 \mu \mathrm{mol} \mathrm{m} \mathrm{m}^{-2} \mathrm{~h}^{-1}$ of $\mathrm{NH}_{4}$ (Fig. 4). However, after uptake by microphytobenthos at the interface, the ammonium flux reaching the water column is about 40 $\mu \mathrm{mol} \mathrm{m}{ }^{-2} \mathrm{~h}^{-1}$. These fluxes are about the same order of magnitude as those estimated or cited by Hopkinson (1987): between 8 and $300 \mu \mathrm{mol} \mathrm{m}{ }^{-2} \mathrm{~h}^{-1}$. Theoretical
Table 2. Contribution of feed water and benthic fluxes to the DIN budget in the water column for $14 \mathrm{~d}$ of batch mode growth

\begin{tabular}{|lcccc|}
\hline Season & $\begin{array}{c}\text { Feed water } \\
\left(\mu \mathrm{mol} \mathrm{I}^{-1}\right)\end{array}$ & $\begin{array}{c}\text { Sediment } \\
\left(\mu \mathrm{mol} \mathrm{I}^{-1}\right)\end{array}$ & $\begin{array}{c}\text { Total } \\
\left(\mu \mathrm{mol} \mathrm{I}^{-1}\right)\end{array}$ & $\begin{array}{c}\text { Sediment } \\
(\% \text { total })\end{array}$ \\
\hline Spring & 32 & 73.0 & 105.0 & 70 \\
Summer & 11 & 72.5 & 83.5 & 87 \\
Autumn & 37 & 61.6 & 98.6 & 62 \\
Winter & 65 & 45.8 & 110.8 & 41 \\
\hline
\end{tabular}

fluxes from sediment under oysters can reach 1100 $\mu \mathrm{mol} \mathrm{m} \mathrm{m}^{-2} \mathrm{~h}^{-1}$, and are in good agreement with fluxes measured at the interface $\left(950 \mu \mathrm{mol} \mathrm{m}{ }^{-2} \mathrm{~h}^{-1}\right)$. As the water depth does not exceed $1 \mathrm{~m}$, the regulation of primary production by the sediment flux is much more important in our study site than in other coastal or estuarine areas (Table 2).

Taking into account the respective areas for the 2 types of sediments in the pond under study, the water column enrichment in nitrogen by fluxes coming from the sediment is about $0.2 \mu \mathrm{mol} \mathrm{l}^{-1} \mathrm{~h}^{-1}$, or $4.8 \mu \mathrm{mol} \mathrm{l} \mathrm{l}^{-1}$ $\mathrm{d}^{-1}$. In summer, the daily nutrient supply from the sediment is therefore equivalent to the total monthly supply by external feed water $\left(6.5 \mu \mathrm{mol} \mathrm{l}^{-1}\right)$. For a budget over $14 \mathrm{~d}$ of batch mode growth, the sediment supplies 10 times more DIN than the feed water, and allows the phytoplankton development observed at this time when the maximal metabolic demand occurs.

In conclusion, environments such as the one studied are subjected to 2 modes of nutrient supplies: a continuous one from the sediment, over which is superimposed a discontinuous one. The latter results from water renewal, whose frequency was monthly in the present case, but can also be variable. This change in nutrient regime also corresponds to a change in the $\mathrm{N}$ source, with mainly ammonium coming from the sediment, and nitrate from the feed water (Collos et al. 1988). As in this (Robert et al. 1986) and other (Glibert et al. 1982) kinds of environments, microalgal succession may be regulated by the nature of the $\mathrm{N}$ nutrients.

Acknowledgements. This work was supported by an IFREMER fellowship to J. M. Sornin, and partly funded by the PIREN-CNRS (grant 82-636). We thank Mrs F. Mornet for technical assistance in nutrient analyses.

\section{LITERATURE CITED}

Balzer, W. (1984). Organic matter degradation and biogenic element cycling in a nearshore sediment (Kiel Bight). Limnol. Oceanogr. 29: 1231-1246

Berner, R. A. (1976). The Benthic Boundary Layer from the viewpoint of a geochemist. In: McCave, I. N. (ed.) The Benthic Boundary Layer. Plenum, New York, p. 33-55 
Billen, G. (1977). Etude écologique des transformations de l'azote dans les sédiments marins. Thèse Doct. en Science, Université de Bruxelles

Billen, G. (1982). Modelling the processes of organic matter degradation and nutrient recycling in sedimentary systems. In: Nedwell, D. B., Brown, C. M. (eds.) Sediment microbiology. Academic Press, London, p. 15-52

Blackburn, T.H.(1980). Seasonal variationsin the rate of organic$\mathrm{N}$ mineralization in anoxic marine sediments. In: Biogéochimie de la matière organique à l'interface eausédiment marin. Colloques int. Cent. natn. Rech. Scient. 293: $73-184$

Boucher, G., Boucher-Rodoni, R. (1988). In situ measurement of respiratory metabolism and nitrogen fluxes at the interface of oyster beds. Mar. Ecol. Prog. Ser. 44: 229-238

Boynton, W. R., Kemp, W. M. (1985). Nutrient regeneration and oxygen consumption by sediments along an estuarine salinity gradient. Mar. Ecol. Prog. Ser. 23: 45-55

Christensen, J. P., Rowe, G. T., Clifford, C. H. (1983). The possible importance of primary amino nitrogen in nitrogen regeneration by coastal marine sediments in Buzzards Bay, Massachusetts. Int. Revue ges. Hydrobiol. 68: 501-512

Collos, Y., Manaud, F., Ravail, B., Cronin, A., Chaigneau, S. (1988). Phytoplankton growth dynamics in temperate coastal marine ponds subjected to natural populations. In: Stadler, T. et al. (eds.) Algal biotechnology. Elsevier Applied Science Publications, London, p. 345-353

Feuillet-Girard, M., Héral, M., Sornin, J. M., Deslous-Paoli, J. M., Robert, J. M. (1988). Eléments azotés de la colonne d'eau et del'interface eau-sédiment du bassin de MarennesOléron: influence des cultures d'huîtres. Aquat. Living Resour. 1: 251-265

Gardner, W. D. (1980a). Sediment trap dynamics and calibration: a laboratory evaluation. J. mar. Res. 38: 17-39

Gardner, W. D. (1980b). Field assessment of sediment traps. J. mar. Res. 38: 41-52

Glibert, P. M., Goldman, J. C., Carpenter, E. J. (1982). Seasonal variations in the utilization of ammonium and nitrate by phytoplankton in Vineyard Sound, Massachusetts, USA. Mar. Biol. 70: 237-249

Gouleau, D., Ottman, F., Chaigneau, M. (1986). Sur un appareillage destiné à l'étude des flux à l'interface eau/sédiment des vasières littorales. J. Rech. Océanogr. 11: 60-62

Hargrave, B. T. (1978). Seasonal changes in oxygen uptake by settled particulate matter and sediments in a marine bay. J. Fish. Res. Bd Can. 35: 1622-1628

Hargrave, B. T., Phillips, G. A. (1986). Dynamics of the benthic food web in St. Georges Bay, southern gulf of St. Lawrence. Mar. Ecol. Prog. Ser. 31: 277-294

Hedges, J. I., Stern, J. H. (1984). Carbon and nitrogen determinations of carbonate-containing solids. Limnol. Oceanogr. 29: $657-663$

Henricksen, K., Jensen, A., Rasmussen, M. B. (1984). Aspects of nitrogen and phosphorus mineralization and recycling in the northern part of the Danish Wadden Sea. Netherlands Institute for Sea Research, Texel, Publ. Ser. 10, p. 51-69

Holm-Hansen, O., Lorenzen, C. J., Holmes, R. W., Strickland, J. D. H. (1965). Fluorometric determination of chlorophyll. J. Cons, perm. int. explor. Mer 30: 3-15

Hopkinson, C. S. (1987). Nutrient regeneration in shallow-water sediments of the estuarine plume region of the nearshore Georgia Bight, USA. Mar. Biol. 94: 127-142

Jørgensen, B. B., Sørensen, J. (1985). Seasonal cycles of $\mathrm{O}_{2}, \mathrm{NO}_{3}$ and $\mathrm{SO}_{4}$ reduction in estuarine sediments: the significance

This article was submitted to the editor of an $\mathrm{NO}_{3}$ reduction maximum in spring. Mar. Ecol. Prog. Ser. $24: 65-74$

Kaspar, H. F., Gillespie, P. A., Boyer, I. C., Mackenzie, A. L. (1985). Effects of mussel aquaculture on the nitrogen cycle and benthic communities in Kenepuru Sound, Marlborough Sounds, New Zealand. Mar. Biol. 85: 127-136

Kemp, W. M., Boynton, W. R. (1984). Spatial and temporal coupling of nutrient inputs to estuarine primary production: the role of particulate transport and decomposition. Bull. mar. Sci. 35: 522-535

Krom, M. D., Berner, R. A. (1980). The diffusion coefficients of sulfate, ammonium and phosphate ions in anoxic marine sediments. Limnol. Oceanogr. 25: 327-337

Kusuki, Y. (1981). Fundamental studies of the deterioration of oyster growing grounds. Bulletin of the Hiroshima Fisheries experimental Station 11: 1-93

Maestrini, S. Y., Robert, J. M. (1981). Rendements d'utilisation des sels nutritifs et variations de l'état des cellules de trois diatomées de claires à huîtres de Vendée. Oceanologica Acta 4: 13-21

Nixon, S. W. (1981). Remineralization and nutrient cycling in coastal marine ecosystems. In: Neilson, B. J., Cronin, L. E. (eds.) Estuaries and nutrients. Humana Press, Clifton, p. 111-138

Petty, R. L., Michel, W. C., Snow, J. P., Johnson, K. S. (1982) Determination of total primary amines in sea water and plant nectar with flow injection sample processing and fluorescence detection. Analytica Chim. Acta 142: 299-304

Redfield, A. C., Ketchum, B. H., Richards, F. A. (1963). The influence of organisms on the composition of seawater. In: Hill, M. N. (ed.) The sea, Vol. 2. Interscience, New York, p. 25-77

Robert, J. M. (1983). Fertilité des eaux des claires ostréicoles et verdissement: utilisation de l'azote par les diatomées dominantes. Thèse Doctorat ès Sciences, Université de Nantes

Robert, J. M., Maestrini, S. Y., Héral, M., Rincé, Y., Dreno, J. P. Beker, L. (1982). Enrichissement expérimental d'eaux printanières de claires à huîtres en baie de Bourgneuf (Vendée, France): augmentation de la biomasse et utilisation des éléments nutritifs par les algues unicellulaires. Hydrobiologia 96: 53-63

Robert, J. M., Vincendeau, M. L., Maestrini, S. Y., Marion, A. (1986). Prises simultanées de l'azote minéral et de l'urée par les algues unicellulaires des claires ostréicoles: effet de la source d'azote sur la nature du peuplement. C. R. Acad. Sci. Paris 303, Série III: $167-170$

Rudnick, D. T., Oviatt, C. A. (1986). Seasonal lags between organic carbon deposition and mineralization in marine sediments. J. mar. Res. 44: 815-837

Sornin, J. M., Feuillet, M., Héral, M., Deslous-Paoli, J. M. (1983). Effet des biodépôts de l'huître Crassostrea gigas (Thunberg) sur l'accumulation de matières organiques dans les parcs du bassin de Marennes-Oléron. J. Mollusc. Stud. 12A: 185-197

Sornin, J. M., Delmas, D., Deslous-Paoli, J. M. (1987). Evolutions quantitatives et qualitatives du seston dans une claire à huîtres: relation avec la sédimentation et la biodéposition. Océanis 13: 531-541

Strickland, J. D. H., Parsons, T. R. (1968). A manual of sea water analysis. Bull. Fish. Res. Bd Can. 167: 1-311

Zanette, Y. (1980). Intervention de quelques facteurs dans l'évolution de la biomasse des claires de Marennes-Oléron. Cons. Int. Explor. Mer. C.M.-ICES/L 45: 1-11

Manuscript first received: November 4, 1988

Revised version accepted: August 13, 1990 